PERM JOURNAL OF PETROLEUM AND MINING ENGINEERING ВЕСТНИК ПНИПУ. ГЕОЛОГИЯ. НЕФТЕГАЗОВОЕ И ГОРНОЕ ДЕЛЮ

ISSN 2224-9923

Volume / Toм 19 №1 2019

http://vestnik.pstu.ru/geo/

UDC 622.276+622.361.16:544.722.54

Article / Статья

(C) PNRPU / ПНИПУ, 2019

\title{
THE CHANGE OF ADHESION FORCES ON THE SURFACE OF THE MONTMORILLONITE CLAY PARTICLES DURING HIGH PRESSURE PROCESSING
}

\section{Maksim V. Fedorov, Igor V. Lunegov, Natalia A. Medvedeva, Mikhail F. Leonovich, Aleksander V. Rastegaev ${ }^{1}$}

Perm State National Research University (15, Bukirevast., Perm, 614990, Russian Federation)

${ }^{1}$ Perm National Research Polytechnic University (29, Komsomolskiy ave., Perm, 614900, Russian Federation)

\section{ИЗМЕНЕНИЕ СИЛ АДГЕЗИИ НА ПОВЕРХНОСТИ ЧАСТИЦ ПРИ ОБРАБОТКЕ МОНТМОРИЛЛОНИТОВОЙ ГЛИНЫ ВЫСОКИМ ДАВЛЕНИЕМ}

\section{М.В. Федоров, И.В. Лунегов, Н.А. Медведева, М.Ф. Леонович, А.В. Растегаев ${ }^{1}$}

Пермский государственный национальный исследовательский университет (614990, Россия, г. Пермь, ул. Букирева, 15) ${ }^{1}$ Пермский национальный исследовательский политехнический университет (614900, Россия, г. Пермь, Комсомольский пр., 29)

Received / Получена: 17.09.2018. Accepted / Принята: 14.01.2019. Published / Опубликована: 29.03.2019

Key words:

montmorillonite, clay, pressure, adhesion force, clay particle,

colloid, particle surface roughness, atomic force microscopy, adsorption water, water film thickness, surface energy activity, surface charge, silicon cantilever, microrelief, correlation matrix.

\begin{abstract}
For the formation of the technological properties of clays, various methods for their processing have been developed: thermal, chemical, ultraviolet mechanical and others. However, the issues of changing the properties of clays and clay particles, previously compacted with high pressures, are not well understood. Therefore, the aim of the work is to study the patterns of change in adhesion forces on the surface of particles of montmorillonite clay treated with stress pressure and shear. The adhesion force on the surface of clay particles and in the space between them was measured by atomic force microscopy on previously prepared samples of montmorillonite clay, compacted under different pressure (from 25 to $800 \mathrm{MPa}$ ).

Experimental results showed that with increasing pressure on montmorillonite, adhesion forces change. So, with an increase in compaction pressure from 25 to $200 \mathrm{MPa}$, adhesion forces increase from 0.32 to $0.70 \mathrm{nN}$. When exposed to pressures above $200 \mathrm{MPa}$, adhesion forces decrease (to $0.40 \mathrm{nN}$ at $\mathrm{P}=800 \mathrm{MPa}$ ).

To explain the dependence of the strength of adhesion of montmorillonite on the compaction pressure, the roughness of the samples and the amount of adsorbed water on their surface were studied. It is revealed that the roughness and thickness of the water film on the surface of the clay particle increases with increasing pressure. An increase in the thickness of the water film is probably due to the defects on the particle surface caused by pressure and shear. The presence of additional defects causes an increase in the charge density on the surface of the particles, increasing the number of adsorbed water molecules and the thickness of the water film, respectively.
\end{abstract} Для формирования технологических свойств глин разработаны различные способы их обработки: тепловая, химическая, ультрафиолетовая, механическая и другие. Однако вопросы изменения свойств глин и глинистых частиц, предварительно уплотненных высоким давлением, изучены недостаточно. Поэтому целью работы является изучение закономерностей изменения сил адгезии на поверхности частиц монтмориллонитовой глины, обработанной стрессовым давлением и сдвигом. Сила адгезии на поверхности глинистых частиц и в пространстве между ними была измерена методом атомно-силовой микроскопии на заранее подготовленных образцах монтмориллонитовой глины, уплотненных под различным давлением (от 25 до 800 МПа).

Результаты экспериментов показали, что с ростом давления на монтмориллонит силы адгезии изменяются. Так, при возрастании давления уплотнения от 25 до 200МПа силы адгезии увеличиваются с 0,32 до 0,70 нН. При воздействии давлений свыше 200МПа силы адгезии уменьшаются (до 0,40 нН при $P=800 \mathrm{MПа).}$

Для объяснения подобной зависимости силы адгезии монтмориллонита от давления уплотнения были изучены шероховатость образцов и количество адсорбированной воды на их поверхности. Выявлено, что шероховатость и толщина водной пленки на поверхности глинистой частицы возрастают с ростом давления. Увеличение толщины водной пленки, вероятно, связано с ростом дефектов на поверхности частицы, вызванных давлением и сдвигом. Наличие дополнительных дефектов вызывает повышение плотности заряда на поверхности частиц, увеличивая количество адсорбированных молекул воды и толщину водной пленки соответственно.

Maksim V. Fedorov - Master's student at the Department of Engineering Geology and subsoil protection (tel.: +007 3422396439 , +0079655733624 , -mail: fedorovmaxim5035@gmail.com). The contact person for correspondence.

Igor V. Lunegov (Author ID in Scopus: 56330315900) - PhD in Physical and Mathematical Sciences, Associate Professor, Head of the Department of Radio electronics and information security (tel.: +007 34223965 52, e-mail: lunegov@psu.ru).

Natalia A. Medvedeva (Author ID in Scopus: 55164437300) - PhD in Chemistry, Associate Professor at the Department of Physical Chemistry (tel.: +007 342 239 63 15, e-mai: nata-kladova@yandex.ru).

Mikhail F. Leonovich - PhD, Associate Professor at the Department of Engineering Geology and subsoil protection (tel.: +007 342 239 64 39, e-mail: leonovichmf@mail.ru). Aleksander V. Rastegaev (Author ID in Scopus: 55531816900) - Doctor of Geology and Mineralogy, Professor of the Department of Geology of Oil and Gas (tel.: +007 34221983 14, e-mail: arastegaev@mail.ru).

Федоров Максим Вячеславович - магистрант кафедры инженерной геологии и охраны недр (тел.: +007342 23964 39 , +007965 573 3624 , e-mail: fedorovmaxim5035@gmail.com). Контактное лицо для переписки.

Лунегов Игорь Владимирович - кандидат физико-математических наук, доцент, заведующий кафедрой радиоэлектроники и защиты информации (тел.: +007 3422396552 , e-mail: lunegov@psu.ru).

Медведева Наталья Александровна - кандидат химических наук, доцент, преподаватель кафедры физической химии (тел.: +007 34223963 15, e-mail: nata-kladova@yandex.ru). Леонович Михаил Фадеевич - кандидат технических наук, доцент, преподаватель кафедры инженерной геологии и охраны недр (тел.: +007 3422396439 , e-mail: leonovichmf@mail.ru).

Растегаев Александр Васильевич - доктор геолого-минералогических наук, профессор кафедры геологии нефти и газа (тел.: +007342 2198314 , e-mail: arastegaev@mail.ru). 


\section{Introduction}

It is known that on the surface of clay particles there is uncompensated negative charge, the formation of which is most affected by cations isomorphic substitution in tetrahedral or octahedral sheets of clay minerals [1-7].

The change in adhesion strength depends on the surface potential and surface charge density. The average surface potential of montmorillonite, according to [8], is $-62.8 \pm 10.6 \mathrm{mV}$. Using an atomic force microscope (AFM), it was found that with increasing charge density of clay minerals, the adhesion force increases.

In $[9,10]$, it was shown that the adhesion force is greatly influenced by the clay particle surface morphology (roughness), and with decreasing roughness, the adhesion force increases. In [11] authors indicate that with a decrease in the roughness of the silicon surface from 13.7 to $0.67 \mathrm{~nm}$, the adhesion force increases 12 times (from 90 to $1080 \mathrm{nN}$ ) at a humidity close to zero. Leite et al. [12], studying the substrates of mica and silicon oxide, found that the average adhesion force between the silicon tip and the smooth surface of mica is $26.6 \pm 0.4 \mathrm{nN}$, and the rough surface of silicon oxide is $19.0 \pm 1,7 \mathrm{nN}$ It is assumed that the dispersion is higher in a rough substrate.

Studies [13-15] showed that the type and properties of the film covering the surface of the particles have a great influence on the adhesion force changes. Thus, with an increase in the water film thickness (at a moisture content of up to $70 \%$ ) on a smooth silicon surface, the adhesion force increases by $40 \%$, and for a rough surface by $400 \%$ [11]. When the silicon oxide surface was contaminated with hydrocarbons, the adhesion force decreased as compared with the cleaned surface [12]. The mechanisms of the surface water films formation and their properties are given in the works of V.I. Osipova, V.N. Sokolova and V.T. Trofimov [16-18].

For the formation of desired clays properties (sorption capacity, plasticity, stickiness, adhesion), various methods have been developed. Thus, during the clays heat treatment high-energy centers on the surface of the mineral are releasing $[19,20]$. Grigoriev et al. [21] found that mechanical treatment of titanium carbide powder in a ball mill leads to a decrease in the size of the coherent scattering field. V.V. Boldyrev, in a review paper, noted that pressures affect changes in the structure of a solid particle, primarily the concentration of various types of defects [22]. In the works of J.A. Sapronov [23] and S.P. Nichiporenko et al. [24] ultraviolet and ultrasonic activation of clays are carried out, respectively. All of the above methods cause an increase in the particles surface charge density, due to which an increase in adhesion forces occurs.

A limited number of studies are devoted to the study of the treated with pressure clay soils physicochemical properties. LaIglesia [25] found that when kaolinite samples are subjected to pressure in the range of $100-2000 \mathrm{MPa}$, the coherent dispersion field size (D100) does not change significantly, and at pressures greater than $4000 \mathrm{MPa}$, these changes occur. Studies by Galán et al. [7] showed that when processing kaolinite with pressures up to $13,200 \mathrm{~kg} / \mathrm{cm}^{2}$ (bar), structural changes-defects are formed in it. Isostatic pressure effects on the defects formation 1.4 times higher than that of dry uniaxial pressure. Investigating kaolinite at pressures of 150-2300 bar, E.A. Goylo [26, 27] found that stress pressure is the main cause of disorder in the kaolinite structure. V.A. FrankKamenetsky et al. [28, 29], V.V. Boldyrev [22] et al. came to similar conclusions

When pressure is applied to kaolinite, its physicomechanical properties change [30]; for example it is transformed into dikkit, potassiumfeldspar, etc. [27, 31-33].

Thus, despite the available research, the issues of the surface adhesion forces changing of the compacted clay particles by high pressure, are not fully understood.

Therefore, the aim of the work is to study the patterns of the particles surface adhesion forces 
changes during the machining of montmorillonite clay with high pressure and shear.

\section{Research methodology}

\section{Sample preparation}

The object of the study was montmorillonite clay of the Lobanovsky district. A fraction of less than $0.01 \mathrm{~mm}$ was extracted from the natural clay by the sedimentation method. The mineral composition of this fraction was determined by X-ray analysis. According to its results, in the initial clay samples the dominance of montmorillonite $(75.0 \%)$ and quartz (11.4\%) was revealed. In addition to montmorillonite, the presence of albite $(6.7 \%)$, kaolinite $(3.6 \%)$ and calcite $(3.3 \%)$ is also observed. The density of clay particles is $2.73 \mathrm{~g} / \mathrm{cm}^{3}$, hygroscopic humidity $-3.59 \%$.

To determine adhesion forces preparation of montmorillonite clay samples was carried out as follows: dried at room temperature natural clay was placed in a mortar and ground with to powder. Then a powder weighing about $0.2 \mathrm{~g}$ was placed in the working area (position 3, Fig. 1, $b$ ) of the device. The working surfaces of the device 3 are made of carbide material, the area was $\mathrm{S}=0.78 \mathrm{~cm}^{2}$. As a load device was used press brand PLG-20. After that, the press 6 supplied the vertical pressure on the ground according to the following scheme: the first stage $-P=25 \mathrm{MPa}$, on the second and subsequent stages the vertical pressure increased by $P=25-50 \mathrm{MPa}$. The maximum pressure was $800 \mathrm{MPa}$. The pressure on the powder was maintained for 1 minute, after which the upper holder 2 was moved relative to the lower holder 1 by $90^{\circ}$ by the handles 4 turning.

As a result, compacted "tablet" samples of montmorillonite clay weighing about $0.2 \mathrm{~g}$ and about $1 \mathrm{~cm}$ in diameter were obtained (see Fig. 1,c).

\section{Measurements of roughness and surface adhesion forces of the particles}

Measurements of adhesion and roughness were carried out on an AFM NT-MDT NTEGRA Prima.

At the first stage, the samples roughness was studied (Fig. 2, a). For this purpose, kaolinite clay samples were scanned in semicontact mode using a GOLDEN Silicon Probes NS G10 silicon cantilever with a constant hardness of $3.1-37.6 \mathrm{~N} / \mathrm{m}$ and a tip radius of about $25 \mathrm{~nm}$. The microrelief of the sample surface was studied in a field of view of $10 \times 10$ and $2 \times 2 \mu \mathrm{m}$. Scanning the samples surface allowed us to calculate their arithmetic average roughness according to the formula ISO 4287/1-1997 [34]:

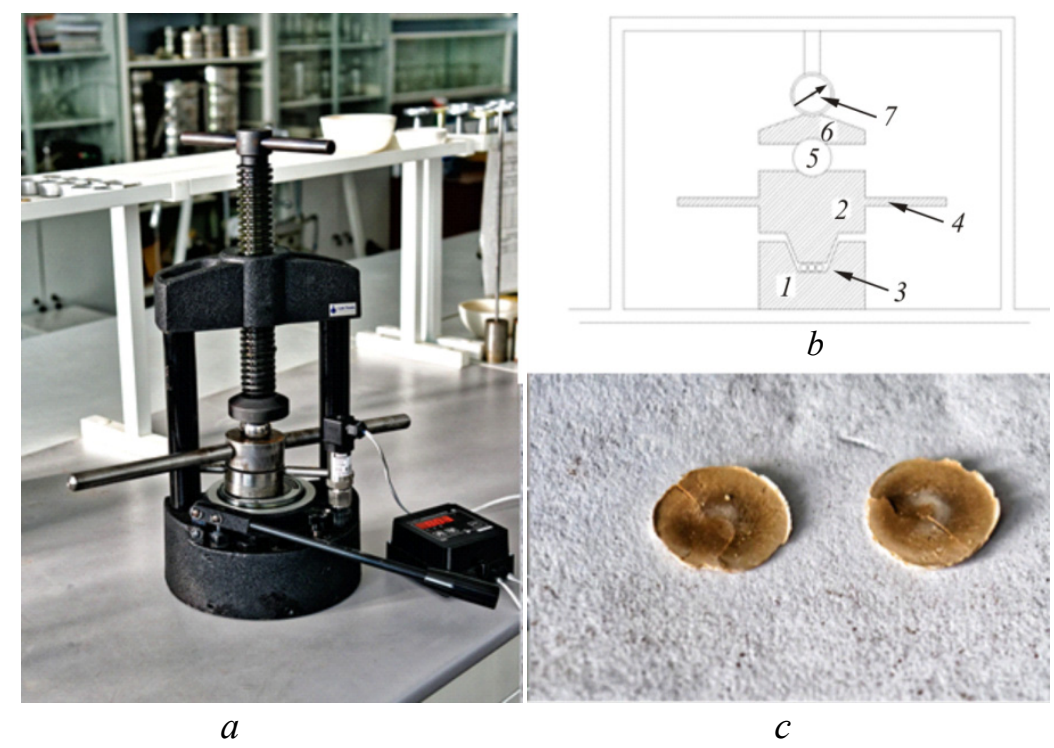

Fig. 1. A device for clay samples compressing and shifting $(a)$ device scheme $(b)$ finished clay samples subjected to compression and shear $(c): 1$ - lower holder; 2 - upper case; 3 - ground shear area of $0.78 \mathrm{~cm}^{2} ; 4$ - handles for the upper case turning (soil shear); 5 - centering ball; 6 - upper plate load device (press); 7 - devices for fixing the transmitted load on the ground 


$$
R_{a}=\frac{1}{N} \sum_{j=1}^{N}\left|r_{j}\right|
$$

where: $\sum_{j=1}^{N}\left|r_{j}\right|$ - the sum of the sample surface roughness measurements; $N$ - number of measurement points.
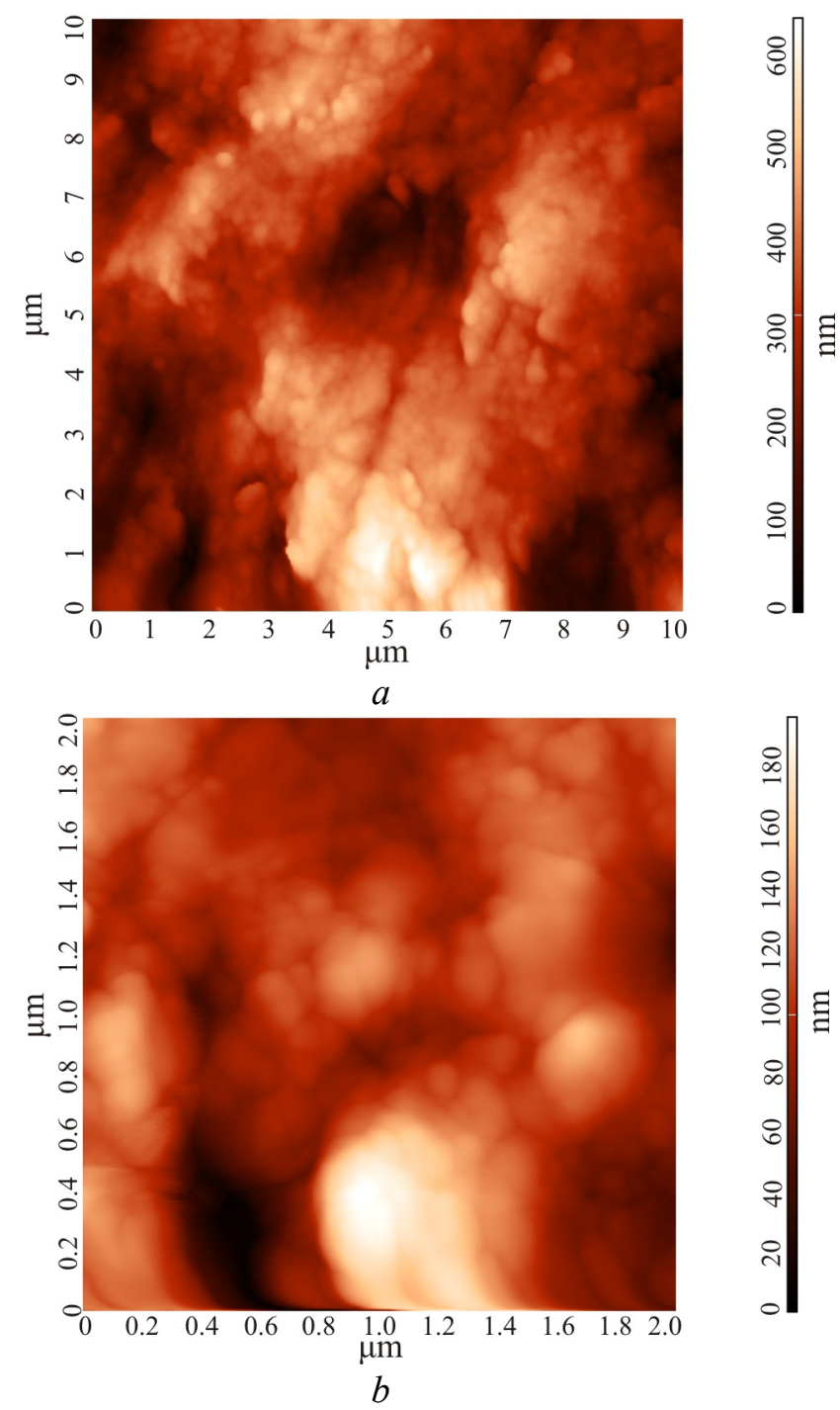

Fig. 2. The morphology of the surface of the compacted under pressure montmorillonite:

$a-100 \mathrm{MPa}$ in the field of view $10 \times 10 \mu \mathrm{m}$;

$\sigma-125 \mathrm{MPa}$ in the field of view $2 \times 2 \mu \mathrm{m}$

At the second stage, the adhesion forces were studied (see Fig. 2, $a$ ) on the surface of the particles (Fn) and in the space between the particles (Fm). The values of adhesion forces were taken from the graphs of the dependence of the force of interaction between the probe and the sample surface on the distance between them (force-distancecurves) [35]. According to the force-distance curve, the adhesion force can be calculated using the following formula:

$$
F=k \cdot \Delta \text { Height, }
$$

where: $k$ - cantilever stiffness, in calculations $k=3,1 \mathrm{~N} / \mathrm{m} ; \Delta$ Height - the difference between the cantilever positions (bending of the console) with a jump to the surface and detachment from it, $\mathrm{nm}[12,35]$.

The adhesion forces measurement was carried out at 10 points both on the surface of the particle and in the space between the particles (see Fig. 2, a). A total of 54 samples were examined.

\section{Calculation of the bound water film thickness on the sample surface}

After montmorillonite clay technogenic processing (compression and shear), samples were obtained. Samples were scanned on AFM in air at a relative humidity of about $30 \%$ (RH), therefore, active adsorption of water from air took place on the surface of clay particles, as a result of which a thin film of bound water was formed.

To calculate the thickness of this film, the following information was used: the loss of mass of compacted montmorillonite clay samples during drying [36] and the change in the active surface area of montmorillonite subjected to shear compression [37]. According to this work, the film of adsorbed water on the surface of montmorillonite completely evaporates at $t=150-200 \mathrm{C}$. Knowing the initial mass of the sample and its mass after drying, the mass of bound water was determined. The ratio of the bound water mass to the active surface area indicates the amount of bound water per unit area. Knowing the mass of one water molecule $\left(2.99 \cdot 10^{-23} \mathrm{~g}\right)$ and its effective diameter $(0.27 \mathrm{~nm})$, we can calculate the film thickness. These calculations were carried out for each value of pressure on the sample. A detailed description of the calculation method is presented in [38]. 


\section{Research results and discussion}

\section{The effect of pressure on the adhesion strength}

The results of experimental studies of changes in adhesion forces on the surface of monotmorillonite samples subjected to compression with a shift are shown in Fig. 3.

Figure 3 shows that with an increase in $P$ from 25 to $200 \mathrm{MPa}$, adhesion forces on the surface of particles and between them increase. A subsequent increase in pressure $(P>20 \mathrm{MPa})$ leads to a decrease in adhesion forces. Thus, visually this samples can be divided into two classes: in the first class, at pressures of $P=25-200 \mathrm{MPa}$, an increase in adhesion forces occurs; in the second $(P=200-800)$, the adhesion forces decrease.

To explain this pattern, we should study the factors that influence the magnitude of adhesion forces. These factors, according to [9, 10, 13-15], include:

- the presence of defects, chips of clay minerals and structural disorders of the crystal lattice, which directly affect the magnitude of the surface energy potential;

- surface roughness of clay particles;

- the presence of adsorbed water layers on the surface, which increase the adhesion force due to capillary forces.

After studying the change in these indicators from compaction pressure, it will be possible to judge their role in the adhesion force formation.

\section{The effect of pressure on the particles surface roughness formation}

The concentration of various kinds of defects and chipping of the mineral, structural damage to the crystal lattice, changes in the interatomic distance and bond angles can be used as criteria for assessing the clay particle surface energy potential [22].

At the same time, different types of crystal planes, growth stages, crystal edges and corners, irregularities in the crystallographic structure of the surface, such as cracks and defects, as well as functional groups and impurities are the main cause of the clay minerals surface heterogeneity [1]. Consequently, the clay particle surface energy potential depends on its heterogeneity (roughness).
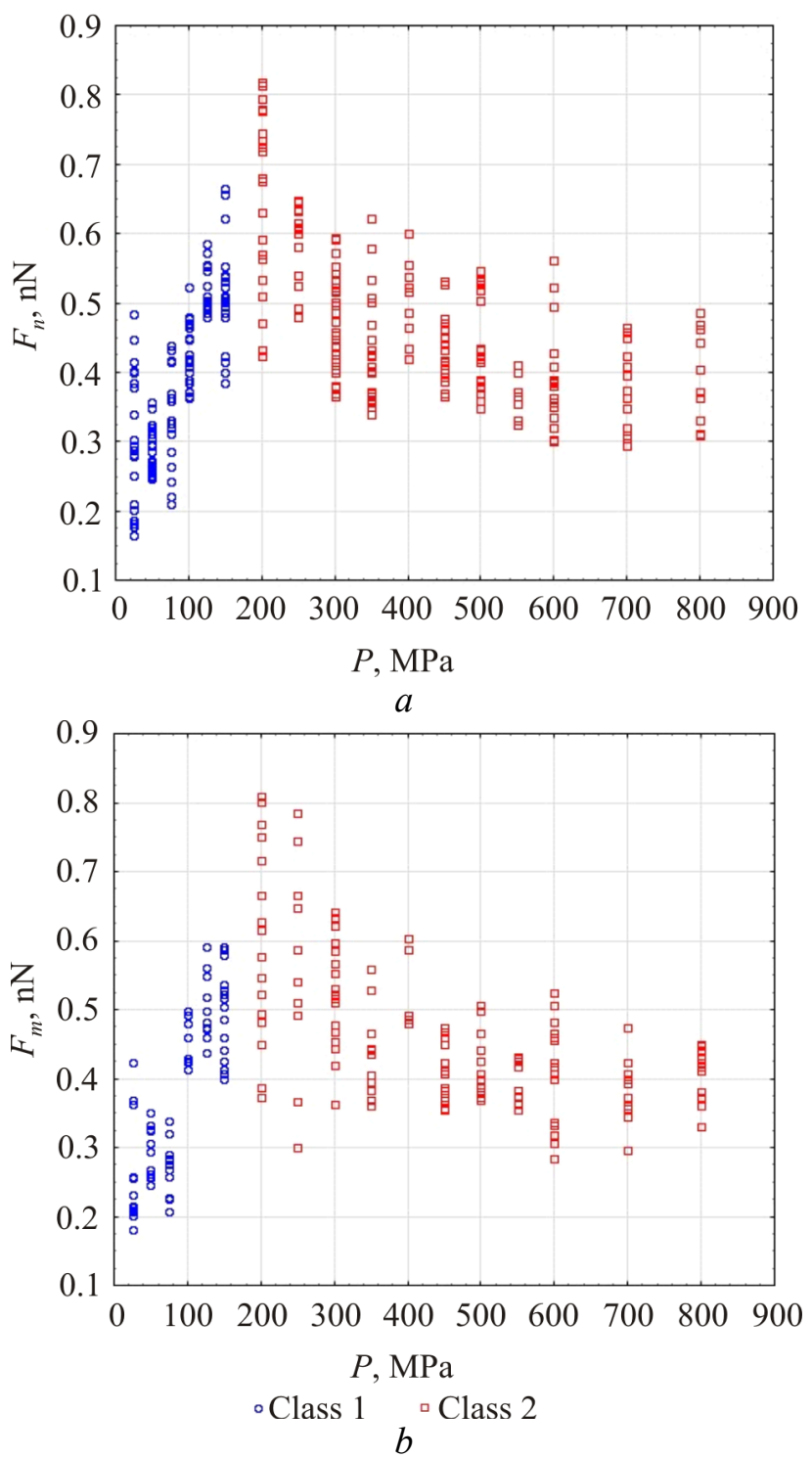

Fig. 3. Change of adhesion forces on the particles surface $\left(F_{n}\right)(a)$ and between particles $F_{m}(b)$ depending on pressure $P$

Surface heterogeneity can be estimated using the average roughness index $\left(R_{c}\right)$, which we will treat in the future as an indicator of the mineral surface energy activity: the higher the roughness, the higher the energy potential of the surface. The change in the montmorillonite average surface roughness from compaction pressure is shown in Fig. 4. 


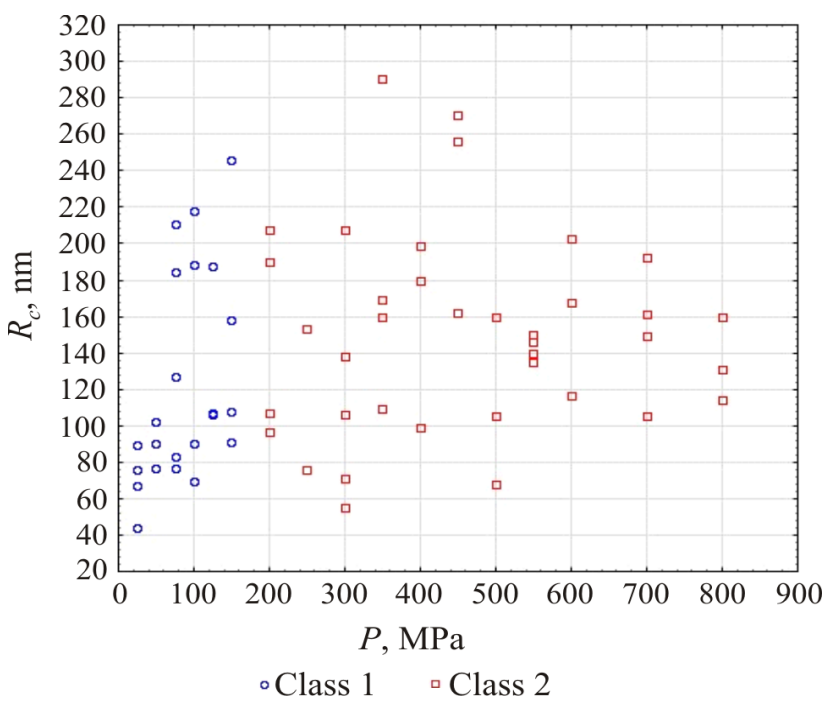

Fig. 4. The change in the average roughness of the clay particles surface depending on the pressure $P$

It is seen that the clay particle surface roughness increases with increasing pressure up to $P=200 \mathrm{MPa}$. With a further increase in pressure to $P=800 \mathrm{MPa}$, a significant variability of $R_{c}$ is observed.

Therefore, at pressures up to $200 \mathrm{MPa}$, the clay minerals surface energy activity increases. In this pressure range (from 25 to $200 \mathrm{MPa}$ ), the shift significantly changes the structure of minerals, additional energy centers are activated, which increase the surface charge density. At a pressure of $200 \mathrm{MPa}$ and above, changes in the minerals structure are insignificant, since the disturbance of their surface occurs at lower pressures.

Thus, the clay minerals energy potential increases at pressures up to $200 \mathrm{MPa}$, activating additional energy centers in defects and cracks. The subsequent increase in pressure does not significantly change the energetics of the clay particles surface.

This conclusion contradicts the results of the adhesion strength measuring. If at loads up to $200 \mathrm{MPa}$, the adhesion force increases with increasing energy potential, then at pressures above $200 \mathrm{MPa}$, the adhesion force decreases, unlike the surface charge, which remains the same. Therefore, other factors that impede the interaction of the surface of the particles and the AFM cantilever should be considered.

\section{Change of bound water film thickness depending on pressure}

Studies conducted by Ata et al., [13]; Biggs et al. [14]; Jones et al. [15] showed that the type and properties of the film covering the particles surface have a great influence on the change in the adhesion force. In the presence of a thin film of bound water on the particles surface, the separation of the AFM probe occurs precisely from it, which increases the value of the adhesion force due to capillary forces. Therefore, it is necessary to take into account the thickness of this film.

In Fig. 5 shows a scatter diagram between the bound water film thickness on the particles surface $\mathrm{H}_{\mathrm{ob}}, \mathrm{nm}$, and the compaction pressure of montmorillonite $P, \mathrm{MPa}$. It can be seen that, when $P=200-300 \mathrm{MPa}$, the thickness of the bound water film increases by more than 2 times. With the subsequent increase in pressure, the film thickness remains almost unchanged and is approximately $31 \mathrm{~nm}$.

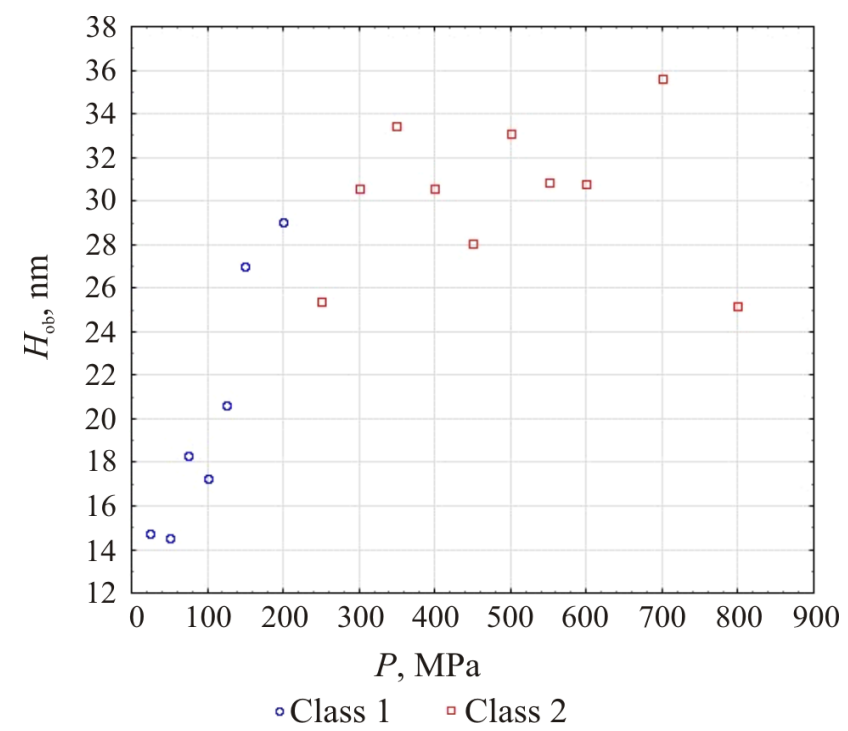

Fig. 5. Changing the bound water film thickness $H_{\mathrm{ob}}$ depending on the pressure $P$

This dependence is consistent with the change in the particles surface energy potential, estimated using the surface roughness parameter (see above). However, this does not explain the decrease in the adhesion force at a pressure above $200 \mathrm{MPa}$; therefore, below we 
consider the direct influence of the surface roughness and the bound water film thickness on the adhesion forces.

\section{Analysis of the effect of roughness and the bound water film thickness} on the adhesion force of montmorillonite clay

All the dependencies discussed above have a similar structure: the sampling data can be visually divided into two classes: 1 st class with $P \leq 200 \mathrm{MPa}$; 2nd class - at $P>200 \mathrm{MPa}$ (Fig. 6). A pressure of $200 \mathrm{MPa}$ should be taken as the critical pressure at which the adhesion forces formation conditions change.
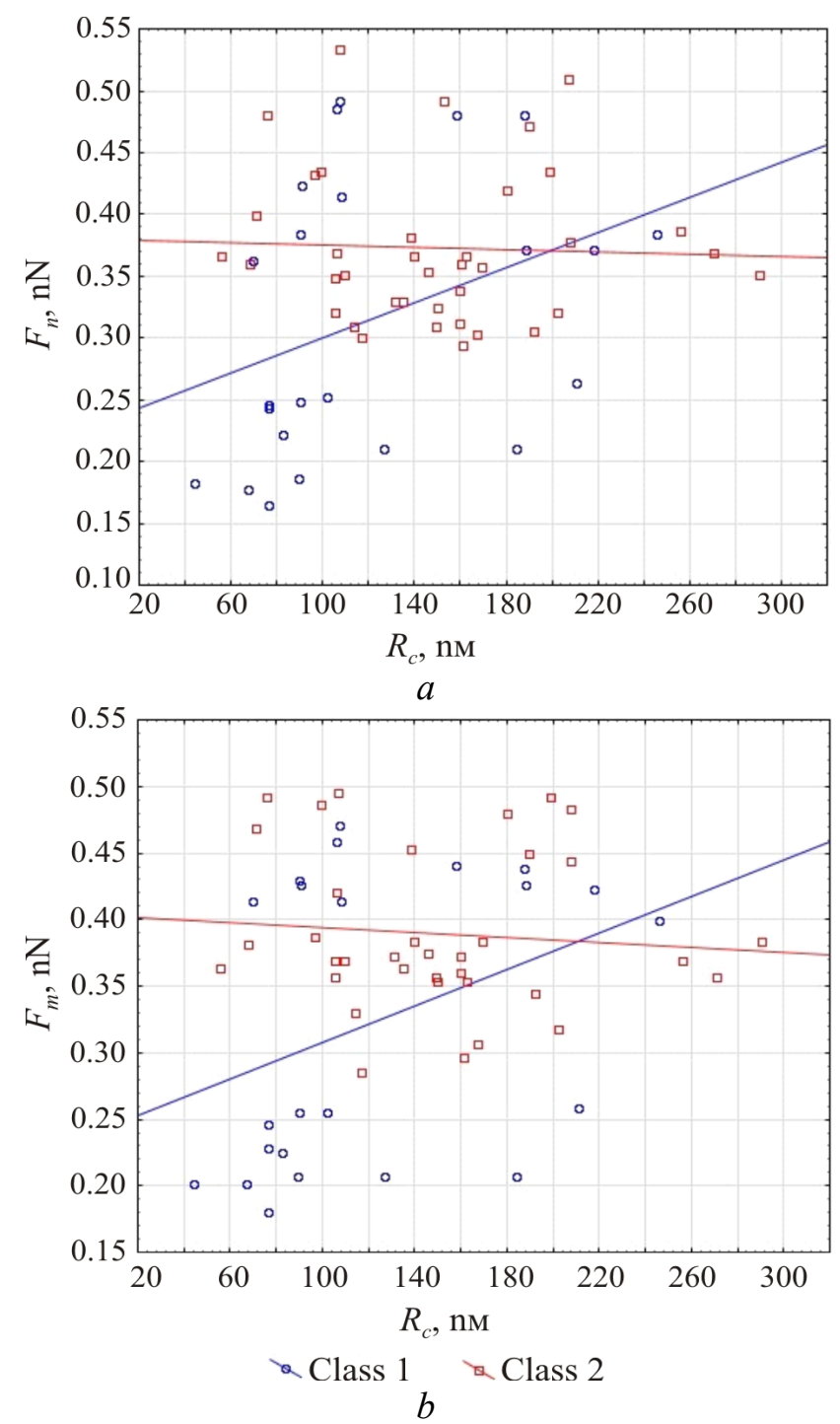

Fig. 6. Effect of roughness Rc on the adhesion force of the surface of the particles $F_{n}(a)$ and between them $F_{m}(b)$
Figure 6 shows how compaction pressure, surface roughness and bound water film thickness affect the adhesion force. Of course, there is no reason to talk about the linear dependence of the adhesion strength and roughness with such a spread of research points. However, this is done to compare the change in adhesion from roughness in classes. It can be seen that in the first class with increasing roughness and thickness of the bound water film adhesion forces increase. Thus, the conclusion is confirmed that the clay minerals energy potential, estimated through the roughness parameter, increases at pressures up to $200 \mathrm{MPa}$ due to the activation of additional energy centers in defects and cracks of minerals. The subsequent increase in pressure does not significantly alter the energetics of the clay particles surface, since pressure of about $200 \mathrm{MPa}$ is sufficient for the destruction of minerals.

Figure 7 shows the pattern of change in the adhesion force $F$ depending on the adsorbed water film thickness $H_{o b}$. It is seen that in the first class, with an increase in $H_{o b}$, the adhesion forces $F_{n}$ and $F_{m}$ increase. In the second class, adhesion forces decrease with a further increase in the film thickness. Perhaps this is due to an overabundance of moisture on the particles surface. All surface energy is spent on the adsorption of water, thereby increasing the thickness of the bound water film. The AFM probe "gets stuck" in the layer of this film and with increasing of the water film thickness is farther and farther from the surface, thereby fixing a lower attractive force.

To study the relationship between these indicators correlation analysis was used. Evaluation was made by linkages correlation coefficient. This method is described in $[39,40]$. The results of correlation coefficients calculations between the paired indicators are presented in the table. 
Correlation Matrix

\begin{tabular}{|l|c|c|c|c|c|c|c|c|c|c|}
\hline \multirow{2}{*}{ Indicator } & \multicolumn{9}{|c|}{ Class 1 } & \multicolumn{5}{c|}{ Class 2 } \\
\cline { 2 - 13 } & $\begin{array}{c}P, \\
\mathrm{MPa}\end{array}$ & $\begin{array}{c}F_{n}, \\
n N\end{array}$ & $\begin{array}{c}F_{m}, \\
n N\end{array}$ & $\begin{array}{c}R_{c}, \\
\mathrm{~nm}\end{array}$ & $\begin{array}{c}H_{o b}, \\
\mathrm{~nm}\end{array}$ & $\begin{array}{c}P, \\
\mathrm{MPa}\end{array}$ & $\begin{array}{c}F_{n}, \\
n N\end{array}$ & $\begin{array}{c}F_{m}, \\
n N\end{array}$ & $\begin{array}{c}R_{c}, \\
\mathrm{~nm}\end{array}$ & $\begin{array}{c}H_{o b}, \\
\mathrm{~nm}\end{array}$ \\
\hline$P, \mathrm{MPa}$ & 1 & 0.78 & 0.82 & 0.47 & 0.90 & 1 & -0.59 & -0.58 & 0.02 & 0.12 \\
\hline$F_{\mathrm{n}}, \mathrm{nN}$ & & 1 & 0.97 & 0.35 & 0.69 & & 1 & 0.67 & 0.04 & -0.31 \\
\hline$F_{\mathrm{m}}, \mathrm{nN}$ & & & 1 & 0.36 & 0.68 & & & 1 & -0.06 & -0.25 \\
\hline$R_{c}, \mathrm{~nm}$ & & & & 1 & 0.39 & & & & 1 & 0.02 \\
\hline
\end{tabular}

Note: red color indicates insignificant correlation coefficients.
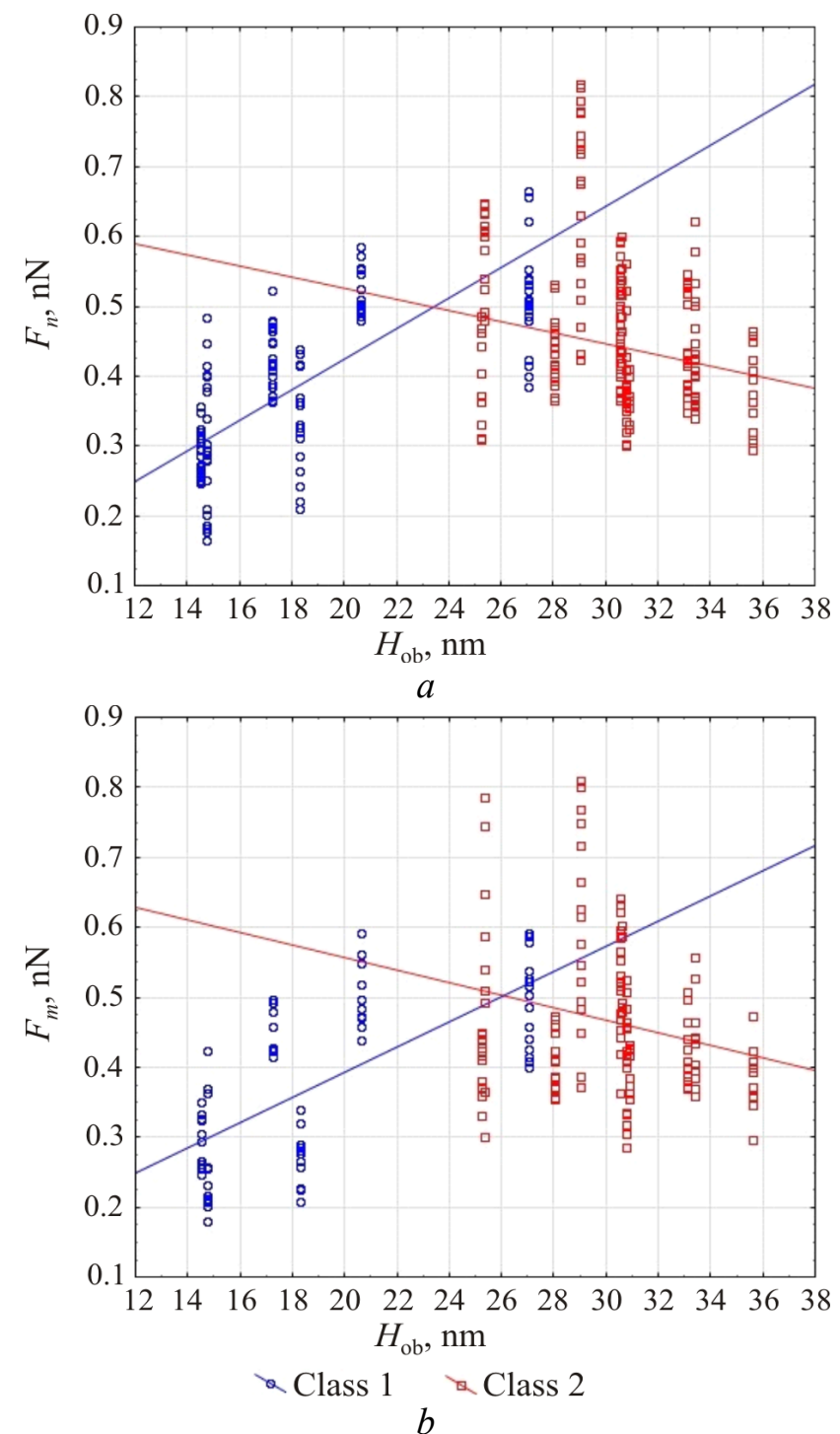

Fig. 7. The effect of the thickness of the bound water

film $H_{o b}$ on the adhesion force of the particles surface $F_{n}(a)$ and between them $F_{m}(b)$

It is seen that in class 1 there is a closer statistical relationship between the indicators than in class 2 . This is evidenced by higher values of the correlation coefficients. So, in class 1 between $P$ and $F_{n}$, the calculated correlation coefficient is $r_{p}=0.83$, and in class $2-r_{p}=-0.49$.
It should be noted that all the obtained calculated values of the correlation coefficients $\left(r_{p}\right)$ are greater than the critical value of the correlation coefficient $\left(r_{\mathrm{T}}=0.24\right)$, calculated for $n=54, \alpha=0.05$. Therefore, we can conclude that pressure affects the formation of adhesion forces on the surface of clay particles and in the space between them. The roughness and thickness of the bound water film, affect the adhesion forces formation in the first class. In the second class, the roughness does not affect the adhesion forces, unlike the water film thickness.

To assess the effect of pressure $(P)$ on the adhesion forces formation, a regression analysis was used, the essence of which is that the higher the value of the angular coefficient at the independent variable $(P)$, the greater the influence exerted on the formation of adhesion forces [39]. Calculated mathematical models have the form:

- for class 1: $F_{\mathrm{n}}=0,2001+0,0022 P$, $F_{\mathrm{m}}=0,1856+0,0021 P$;

- for class 2: $F_{\mathrm{n}}=0,5571-0,0002 P$, $F_{\mathrm{m}}=0,5815-0,0003 P$.

Analysis of the obtained equations shows that in class 1 , the coefficients at $P$ are 7-10 times higher than in class 2 . Therefore, it can be assumed that $P \leq 200 \mathrm{MPa}$ shows a greater influence on the adhesion forces formation than $P>200 \mathrm{MPa}$.

Thus, in the first class, as the pressure increases, the adhesion force on the particles surface and in the space between them increases due to an increase in the surface energy potential, estimated through the roughness parameter. In the second class, adhesion forces decrease due to an increase in the thickness of the bound water film, which prevents the AFM probe from penetrating to the surface.

\section{Conclusion}

The results of experimental studies have shown that during the mechanical processing of kaolinite clay by pressure and shear, the surface roughness of the clay particles increases. The growth of roughness is caused by the growth of defects on the particle surface. The presence of 
additional defects causes an increase in the charge density on the particles surface. An increase in the charge density leads to an increase in the thickness of the water film around the particle. Collectively, an increased charge density and an increased water film thickness on the particle surface increase the adhesion forces. This pattern occurs when $P \leq 200 \mathrm{MPa}$. At pressures above $200 \mathrm{MPa}$, adhesion forces decrease due to an increase in the thickness of the bound water film, which prevents the AFM probe from penetrating to the surface.

\section{References}

1. Rossman F.G., van Oss C.J. Colloid and surface properties of clays and related minerals. Buffalo, New York, University at Buffalo and State University of New York, 2002, 312 p.

2.Zhu X., Zhu Z., Lei X., Yan C. Defects in structure as the sources of the surface charges of kaolinite. Appl. Clay Sci., 2016, vol.124-125, pp.127-136. DOI: 10.1016/j.clay.2016.01.033

3. Shlykov V.G. Rentgenovskii analiz mineralnogo sostava dispersnykh gruntov [X-ray analysis of the mineral composition of dispersed soils]. Moscow, GEOS, 2006, 176 p.

4. Zhou Z., Gunter W.D. The nature of the surface charge of kaolinite. Clay and Clay Minerals, 1992, vol.40, pp.365-368.

5. Kumar N., Zhao C., Klaassen A., van den Ende D., Mugele F., Siretanu I. Characterization of the surface charge distribution on kaolinite particles using high resolution atomic orce microscopy. Geochimica et Cosmochimica Acta, 2016, vol.175, pp.100-112. DOI: 10.1016/j.gca.2015.12.003

6. Tombacz E., Szekeres M. Surface charge heterogeneity of kaolinite in aqueous suspension in comparison with montmorillonite. Appl. Clay Sci., 2006, vol.34, pp.105-124. DOI: 10.1016/j.clay.2006.05.009

7. Galán E., Aparicio P., La Iglesia Â., Gonzalez I. The effect of pressure on order/disorder in kaolinite under wet and dry conditions. Clays and Clay Minerals, 2006, vol.54, no.2, pp.230-239. DOI: 10.1346/CCMN.2006.0540208

8. Guo Y., Xiong (Bill) Yu. Characterizing the surface charge of clay minerals with Atomic Force Microscope (AFM). AIMS Materials Science, 2017, vol.4, no.3, pp. 582-593. DOI: 10.3934/matersci.2017.3.582
9. Persson B.N.J., Tosatti E. The effect of surface roughness on the adhesion of elastic solids. Journal of Chemical Physics, 2001, vol.115, iss.12, pp.5597-5610. DOI: 10.1063/1.1398300

10. Peng Zh. Effects of surface roughness and film thickness on the adhesion of a bio-inspired nanofilm. Bio-inspired Studies on Adhesion of a Thin Film on a Rigid Substrate, 2015, pp.55-70. DOI: 10.1103/PhysRevE.83.051915

11. Çolak A., Wormeester H., Zandvliet H.J.W., Poelsema B. Surface adhesion and its dependence on surface roughness and humidity measured with a flat tip. Applied Surface Science, 2012, vol.258, pp.6938-6942. DOI: 10.1016/j.apsusc.2012.03.138

12. Leite F.L., Ziemath E.C., Oliveira Jr. O.N., Herrmann P.S.P. Adhesion forces for mica and silicon oxide surfaces studied by atomic force spectroscopy (AFS). Microscopy and Microanalysis, 2005, vol.11, no.3, pp.130-133. DOI: $10.1017 / \mathrm{S} 1431927605051068$

13. Ata A., Rabinovich Y.I., Singh R.K. Role of surface roughness in capillary adhesion. Journal of Adhesion Science and Technology, 16(4), pp.337-346. DOI: $10.1163 / 156856102760067145$

14. Biggs S., Cain R.G., Dagastine R.R., Page N.W. Direct measurements of the adhesion between a glass particle and a glass surface in a humid atmosphere Journal of Adhesion Science and Technology, 16:7, pp.869-885. DOI: $10.1163 / 156856102760136445$

15. Jones R., Pollock H.M., Cleaver J.A.S., Hodges C.S. Adhesion forces between glass and silicon surfaces in air studied by AFM: Effects of relative humidity, particle size, roughness, and surface treatment. Langmuir, 2002, 18(21), pp.8045-8055. DOI: 10.1021/la0259196 
16. Osipov V.I. Nanoplenki adsorbirovannoi adsorbirovannoi vody $\mathrm{v}$ glinakh, mekhanizm ikh obrazovaniia i svoistva [Nanofilms of adsorbed water in clays, the mechanism of formation and properties]. Geoekologiya, 2011, no.4, pp.291-305.

17. Osipov V.I., Sokolov V.N. Gliny i ikh svoistva. Sostav, stroenie i formirovanie svoistv [Clay and their properties. Composition, structure and formation of properties]. Moscow, GEOS, 2013, $576 \mathrm{p}$.

18. Trofimov V.T., Korolev V.A., Voznesenskii E.A., Golodkovskaia G.A., Vasilchuk Iu.A., Ziangirov V.S. Gruntovedenie [Soil science]. Moscow, Izdatelstvo Moskovskogo gosudarstvennogo universiteta, 2005, 1024 p.

19. Pushkareva G.I. Vliianie temperaturnoi obrabotki brusita na ego sorbtsionnye svoistva [Effect of temperature treatment of brucite on its sorption properties]. Fiziko-tekhnicheskie problemy razrabotki poleznykh iskopaemykh, 2000, no.6, pp.90-93.

20. Kara-sal B.K., Sapelkina T.V. Povyshenie adsorbtsionnykh svoistv glinistykh porod tuvy $\mathrm{v}$ zavisimosti ot metodov aktivatsii [Improving the adsorption properties of clay rocks of Tuva, depending on the activation methods]. Aktualnye problemy sovremennoi nauki, 2012, no.5, pp.158-162.

21. Grigorev M.V., Molchunova L.M., Buiakova S.P., Kulkov S.N. Vliianie mekhanicheskoi obrabotki na strukturu i svoistva poroshka nestekhiometricheskogo karbida titana [The effect of machining on the structure and properties of non-stoichiometric titanium carbide powder]. Izvestiia vysshikh uchebnykh zavedenii. Fizika, 2013, vol.56, no.7/2, pp.206-210.

22. Boldyrev V.V. Mekhanokhimiia i mekhanicheskaia aktivatsiia tverdykh veshchestv [Mechanochemistry and mechanical activation of solids]. Uspekhi khimii, 2006, vol.75, no.3, pp.203-216.

23. Sapronova Zh.A., Lesovik V.S., Gomes M.Zh., Shaikhieva K.I. Sorbtsionnye svoistva UF-aktivirovannykh glin Angolskikh mestorozhdenii [Sorption properties of UVactivated clays of the Angolan deposits]. Vestnik KazNITU, 2015, vol.18, no.1, pp.91-93.

24. Nichiporenko S.P., Kruglitskii N.N., Panasevich A.A., Khilko V.V. Fiziko-khimicheskaia mekhanika dispersnykh mineralov [Physicochemical mechanics of dispersed minerals]. Kiev, Naukova dumka, 1974, 243 p.

25. La Iglesia A. Pressure induced disorderer in kaolinite. Clay Minerals, 1993, vol.28, pp.311-319. DOI: 10.1180/claymin.1993.028.2.11

26. Goilo E.A. Kristallokhimiia transformatsii sloistykh silikatov [Crystal chemistry oftransformation of layered silicates]. Doctor's degree dissertation. Saint Petersburg, 1997, 70 p.

27. Goilo E.A., Kotov N.V., FrankKamenetskii V.A. Eksperimentalnoe issledovanie vliianiia davleniia i temperatury na kristallicheskie struktury kaolinita, illita i montmorillonita [Experimental study of the effect of pressure and temperature on the crystal structures of kaolinite, illite and montmorillonite]. Fizicheskie metody issledovaniia osadochnykh porod, 1966, pp.123-129.

28. Frank-Kamenetskii V.A., Kotov N.V., Goilo E.A. Izmenenie struktury glinistykh mineralov $\mathrm{v}$ razlichnykh termodinamicheskikh usloviiakh [Changes in the structure of clay minerals in different temodynamic conditions]. Rentgenografiya mineralnogo syrya, 1970, no.7, pp.166-174.

29. Frank-Kamenetskii V.A. Rentgenografiia osnovnykh tipov porodoobrazuiushchikh mineralov (sloistye i karkasnye silikaty) [Radiography of the main types of rock-forming minerals (layered and frame silicates)]. Moscow, Nedra, 1983, 359 p.

30. Seredin V.V., Rastegayev A.V., Panova E.G., Medvedeva N.A. Changes in physicalchemical properties of clay under compression. International Journal of Engineering and Applied Sciences (IJEAS), 2017, vol.4, iss.3, pp.22-29.

31. Kossovskaya A.G., Shutov V.D. Facies of regional epi- and metagenesis. International Geology Review, 1963, vol.7, pp.1157-1167. DOI: 10.1080/00206816509474768

32. Ehrenberg S.N., Aagaard P., Wilson M.J., Fraser A.R., Duthie D.M.L. Depth-dependent 
transformation of kaolinite to dickite in sandstones of the Norwegian continental shelf. Clay Minerals, 1993, vol.28, pp.325-352. DOI: 10.1180/claymin.1993.028.3.01

33. Ruiz Cruz M.D., Andreo B. Genesis and transformation of dickite in PermoTriassic sediments (Betic Cordilleras, Spain). Clay Minerals, 1996, vol.31, pp.133-152.

34. ISO 4287/1-1997. Geometrical Product Specifications (GSP) - Surface texture: Profile method - Terms, definitions and surface texture parameters, available at: http:/files.stroyinf.ru/ Data2/1/4293766/4293766658.pdf (accessed 1 August 2018).

35. Mironov V.L. Osnovy skaniruiushchei zondovoi mikroskopii [Basics of scanning probe microscopy]. Nizhnii Novgorod, RAN Institut fiziki mikrostruktur, 2004, 114 p.

36. Seredin V.V., Parshina T.Iu. Mass change of bound water in clays under compression. Perm Journal of Petroleum and Mining Engineering, 2017, vol.16, no.1, pp.23-32. DOI: 10.15593/2224-9923/2017.1.3

37. Seredin V.V., Rastegaev A.V., Medvedeva N.A., Parshina T.Iu. Vliianie davleniia na ploshchad aktivnoi poverkhnosti chastits glinistykh gruntov [Influence of pressure on the active surface area of clay soil particles]. Inzhenernaia geologiia, 2017, no.3, pp.18-27. DOI: 10.25296/1993-5056-2017-3-18-27

38. Seredin V.V., Fedorov M.V., Lunegov I.V., Medvedeva N.A Zakonomernosti izmeneniia sil adgezii na poverkhnosti chastits kaolinitovoi gliny, podverzhennoi szhatiiu [Regularities of adhesion forces changes on the surface of kaolinite clay particles subjected to compression]. Inzhenernaia geologiia, 2018, vol.13, no.3, pp.8-18. DOI: $10.25296 / 1993-5056-2018-13-3-8-18$

39. Galkin V.I., Rastegaev A.V., Galkin S.V. Veroiatnostno-statisticheskaia otsenka neftegazonostnosti lokalnykh struktur [Probabilisticstatistical evaluation of the petroleum potential of local structures]. Ekaterinburg, URO RAN, 2001, 277 p.

40.Galkin V.I., Seredin V.V., Krasilnikov P.A., Rastegaev A.V. Razrabotka mnogomernykh statisticheskikh modelei dlia inzhenernogeologicheskogo raionirovaniia [Development of the multivariate statistic models for engineering geological zoning of territories]. Geoekologiia, inzhenernaia geologiia, gidrogeologiia, geokriologiia, 2017, no.3, pp.58-66.

\section{Библиографический список}

1. Rossman F.G., Oss van C.J. Colloid and surface properties of clays and related minerals / University at Buffalo and State University of New York. - Buffalo, New York, 2002. - 312 p.

2. Defects in structure as the sources of the surface charges of kaolinite / X. Zhu, Z. Zhu, X. Lei, C. Yan // Appl. Clay Sci. - 2016. - Vol. 124-125. P. 127-136. DOI: 10.1016/j.clay.2016.01.033

3. Шлыков В.Г. Рентгеновский анализ минерального состава дисперсных грунтов. M.: ГEOC, 2006. - 176 c.

4. Zhou Z., Gunter W. D. The nature of the surface charge of kaolinite // Clay and Clay Minerals. - 1992. - Vol. 40. - P. 365-368.

5. Characterization of the surface charge distribution on kaolinite particles using high resolution atomic force microscopy / N. Kumar, C. Zhao, A. Klaassen, D. van den Ende, F. Mugele, I. Siretanu // Geochimica et Cosmochimica Acta. - 2016. - Vol. 175. P. 100-112. DOI: 10.1016/j.gca.2015.12.003

6. Tombacz E., Szekeres M. Surface charge heterogeneity of kaolinite in aqueous suspension in comparison with montmorillonite // Appl. Clay Sci. - 2006. - Vol. 34. - P. 105-124. DOI: 10.1016/j.clay.2006.05.009

7. The effect of pressure on order/disorder in kaolinite under wet and dry conditions / E. Galán, P. Aparicio, Â. La Iglesia, I. Gonzalez // Clays and Clay Minerals 2006. - Vol. 54, no. 2. - P. 230-239. DOI: 10.1346/CCMN.2006.0540208 
8. Guo Y., Xiong (Bill) Yu. Characterizing the surface charge of clay minerals with Atomic Force Microscope (AFM) // AIMS Materials Science. - 2017. - Vol. 4, № 3. P. 582-593. DOI: 10.3934/matersci.2017.3.582

9. Persson B.N.J., Tosatti E. The effect of surface roughness on the adhesion of elastic solids // Journal of Chemical Physics. 2001. - Vol. 115, iss. 12. - P. 5597-5610. DOI: $10.1063 / 1.1398300$

10. Peng $\mathrm{Zh}$. Effects of surface roughness and film thickness on the adhesion of a bioinspired nanofilm // Bio-inspired Studies on Adhesion of a Thin Film on a Rigid Substrate. - 2015. - P. 55-70. DOI: 10.1103/PhysRevE.83.051915

11. Surface adhesion and its dependence on surface roughness and humidity measured with a flat tip / A. Çolak, H. Wormeester, H.J.W. Zandvliet, B. Poelsema // Applied Surface Science. - 2012. - Vol. 258. - P. 6938-6942. DOI: 10.1016/j.apsusc.2012.03.138

12. Adhesion forces for mica and silicon oxide surfaces studied by atomic force spectroscopy (AFS) / F.L. Leite, E.C. Ziemath, O.N. Oliveira Jr., P.S.P. Herrmann // Microscopy and Microanalysis. - 2005. - Vol. 11, № 3. P. 130-133. DOI: 10.1017/S1431927605051068

13. Ata A., Rabinovich Y.I., Singh R.K. Role of surface roughness in capillary adhesion // Journal of Adhesion Science and Technology. - 16(4). - P. 337-346. DOI: $10.1163 / 156856102760067145$

14. Direct measurements of the adhesion between a glass particle and a glass surface in a humid atmosphere / S. Biggs, R.G. Cain, R.R. Dagastine, N.W. Page // Journal of Adhesion Science and Technology. - 16(7). P. 869-885. DOI: 10.1163/156856102760136445

15. Adhesion forces between glass and silicon surfaces in air studied by AFM: effects of relative humidity, particle size, roughness, and surface treatment / R. Jones, H.M. Pollock, J.A.S. Cleaver, C.S. Hodges // Langmuir. - 2002. 18(21). - P. 8045-8055. DOI: 10.1021/la0259196
16. Осипов В.И. Нанопленки адсорбированной воды в глинах, механизм их образования и свойства // Геоэкология. - 2011. - № 4. С. 291-305.

17. Осипов В.И., Соколов В.Н. Глины и их свойства. Состав, строение и формирование свойств. - М.: ГЕОС, 2013. - 576 с.

18. Грунтоведение / В.Т. Трофимов, В.А. Королев, Е.А. Вознесенский, Г.А. Голодковская, Ю.А. Васильчук, В.С. Зиангиров. - М.: Изд-во Моск. гос. ун-та, 2005. - 1024 с.

19. Пушкарева Г.И. Влияние температурной обработки брусита на его сорбционные свойства // Физико-технические проблемы разработки полезных ископаемых. - 2000. № 6. - С. 90-93.

20. Кара-Сал Б.К., Сапелкина Т.В. Повышение адсорбционных свойств глинистых пород Тувы в зависимости от методов активации // Актуальные проблемы современной науки. - 2012. - № 5. - С. 158-162.

21. Влияние механической обработки на структуру и свойства порошка нестехиометрического карбида титана / М.В. Григорьев, Л.М. Молчунова, С.П. Буякова, С.Н. Кульков // Изв. высших учебных заведений. Физика. 2013. - Т. 56, № 7/2. - С. 206-210.

22. Болдырев В.В. Механохимия и механическая активация твердых веществ // Успехи химии. - 2006. - Т. 75, № 3. - С. 203-216.

23. Сорбционные свойства УФ-активированных глин Ангольских месторождений / Ж.А. Сапронова, В.С. Лесовик, М.Ж. Гомес, К.И. Шайхиева // Вестник КазНИТУ. - 2015. Т. 18, № 1. - С. 91-93.

24. Физико-химическая механика дисперсных минералов / С.П. Ничипоренко, Н.Н. Круглицкий, А.А. Панасевич, В.В. Хилько. Киев: Наукова думка, 1974. - 243 с.

25. La Iglesia A. Pressure induced disorderer in kaolinite // Clay Minerals - 1993. - Vol. 28. P. 311-319. DOI: 10.1180/claymin.1993.028.2.11

26. Гойло Э.А. Кристаллохимия трансформации слоистых силикатов: дис. д-ра геол.мин. наук. - СПб., 1997. - 70 с. 
27. Гойло Э.А., Котов Н.В., ФранкКаменецкий В.А. Экспериментальное исследование влияния давления и температуры на кристаллические структуры каолинита, иллита и монтмориллонита // Физические методы исследования осадочных пород. - 1966. - С. 123-129.

28. Франк-Каменецкий В.А., Котов Н.В., Гойло Э.А. Изменение структуры глинистых минералов в различных термодинамических условиях // Рентгенография минерального сырья. - 1970. - № 7. - С. 166-174.

29. Франк-Каменецкий В.А. Рентгенография основных типов породо-образующих минералов (слоистые и каркасные силикаты). М.: Недра, 1983. - 359 с.

30. Changes in physical-chemical properties of clay under compression / V.V. Seredin, A.V. Rastegayev, E.G. Panova, N.A. Medvedeva // International Journal of Engineering and Applied Sciences (IJEAS). 2017. - Vol. 4. iss 3. - P. 22-29.

31. Kossovskaya A.G., Shutov V.D. Facies of regional epi- and metagenesis // International Geology Review. - 1963. - Vol. 7. - P. 1157-1167. DOI: $10.1080 / 00206816509474768$

32. Depth-dependent transformation of kaolinite to dickite in sandstones of the Norwegian continental shelf / S.N. Ehrenberg, P. Aagaard, M.J. Wilson, A.R. Fraser, D.M.L. Duthie // Clay Minerals. - 1993. - Vol. 28. P. 325-352. DOI: 10.1180/claymin.1993.028.3.01

33. Ruiz Cruz M.D., Andreo B. Genesis and transformation of dickite in PermoTriassic sediments (Betic Cordilleras, Spain) // Clay Minerals. - 1996. - Vol. 31. - P. 133-152.

34. ISO 4287/1-1997 Geometrical Product Specifications (GSP) - Surface texture: Profile method - Terms, definitions and surface texture parameters [Электронный pecypc]. URL: http://files.stroyinf.ru/Data2/1/4293766/4293766 658.pdf (дата обращения: 1.08.2018).

35. Миронов В.Л. Основы сканирующей зондовой микроскопии / РАН Институт физики микроструктур. - Н. Новгород, 2004. - 114 c.

36. Середин В.В., Паршина Т.Ю. Изменение масс связанной воды в глинах при сжатии // Вестник Пермского национального исследовательского политехнического университета. Геология. Нефтегазовое и горное дело. - 2017. - Т. 16, № 1. - С. 23-32. DOI: $10.15593 / 2224-9923 / 2017.1 .3$

37. Влияние давления на площадь активной поверхности частиц глинистых грунтов / В.В. Середин, А.В. Растегаев, Н.А. Медведева, Т.Ю. Паршина // Инженерная геология. - 2017. - № 3. - С. 18-27. DOI: $10.25296 / 1993-5056-2017-3-18-27$

38. Закономерности изменения сил адгезии на поверхности частиц каолинитовой глины, подверженной сжатию / В.В. Середин, М.В. Федоров, И.В. Лунегов, Н.А. Медведева // Инженерная геология. 2018. - T. 13, № 3. - C. 8-18. DOI: 10.25296/1993-5056-2018-13-3-8-18

39. Галкин В.И., Растегаев А.В., Галкин С.В. Вероятностно-статистическая оценка нефтегазоностности локальных структур. Екатеринбург: Уро РАН, 2001. - 277 с.

40. Разработка многомерных статистических моделей для инженерно-геологического районирования / В.И. Галкин, В.В. Середин, П.А. Красильников, А.В. Растегаев // Геоэкология, инженерная геология, гидрогеология, геокриология. - 2017. - № 3. - С. 58-66.

Please cite this article in English as:

Fedorov M.V., Lunegov I.V., Medvedeva N.A., Leonovich M.F., Rastegaev A.V.The change of adhesion forces on the surface of the montmorillonite clay particles during high pressure processing. Perm Journal of Petroleum and Mining Engineering, 2019, vol.19, no.1, pp.26-38. DOI: 10.15593/2224-9923/2019.1.3

Просьба ссылаться на эту статью в русскоязычных источниках следующим образом:

Изменение сил агдезии на поверхности частиц при обработке монтмориллонитовой глины высоким давлением / М.В. Федоров, И.В. Лунегов, Н.А. Медведева, М.Ф. Леонович, А.В. Растегаев // Вестник Пермского национального исследовательского политехнического университета. Геология. Нефтегазовое и горное дело. - 2019. - Т.19, №1. - С.26-38. DOI: $10.15593 / 2224-9923 / 2019.1 .3$ 